\title{
HUBUNGAN STRES DENGAN MOTIVASI BELAJAR PADA MAHASISWA FAKULTAS KEDOKTERAN UNIVERSITAS MALAHAYATI ANGKATAN 2018
}

\author{
Dewi Lutfianawati ${ }^{1}$, Dalfian ${ }^{2^{*}}$, Muhammad Marnanda Kahar ${ }^{3}$ \\ ${ }^{1,2}$ Dosen Program Studi Kedokteran Universitas Malahayati \\ ${ }^{3}$ Mahasiswa Program Studi Kedokteran Universitas Malahayati \\ Email Korespondesi: Dalfianadnan@gmail.com
}

\section{ABSTRACK: THE CORRELATION OF STRESS WITH LEARNING MOTIVATION ON STUDENTS IN MEDICAL FACULTY OF MALAHAYATI UNIVERSITY CLASS OF 2018}

Background: Medical students must have high learning motivation to participate in lecture activities properly and are required to be able to learn a lot of material in a short time to match expectations. There are several factors that can affect learning motivation, namely intrinsic and extrinsic factors, while extrinsic factors can be related to learning motivation.

Objective: This study aims to determine the relationship between stress and learning motivation in students of the Faculty of Medicine, Malahayati University class of 2018.

Method: This research is an analytic survey with a cross sectional approach with a total sampling type of sampling technique. The subjects in this study were all 119 students of the Faculty of Medicine, Malahayati University Bandar Lampung, in 2018. Retrieval of data using a questionnaire. The data obtained were analyzed statistically with the chi-square test.

Results: Most of the subjects of this study were female, $73.9 \%$, aged 20 years $35, \%$, had a high motivation level of $45.4 \%$, a moderate stress level of $45.5 \%$.

Conclusion: There is a significant relationship between stress and learning motivation.

Keyword : Stress, Learning Motivation

\section{INTISARI: HUBUNGAN STRES DENGAN MOTIVASI BELAJAR PADA MAHASISWA FAKULTAS KEDOKTERAN UNIVERSITAS MALAHAYATI ANGKATAN TAHUN 2018}

Latar Belakang: Mahasiswa kedokteran harus memiliki motivasi belajar yang tinggi untuk mengikuti kegiatan perkuliahan dengan baik dan dituntut untuk dapat mempelajari materi yang banyak dalam waktu singkat agar sesuai dengan harapan. Terdapat beberapa faktor yang dapat mempengaruhi motivasi belajar, adalah faktor intrinsik dan ekstrinsik sedangakn faktor ektrinsik yang dapat berhubunagn dengan motivasi belajar .

Tujuan: Penelitian ini bertujuan untuk mengetahui hubungan antara stress dengan motivasi belajar pada mahasiswa Fakultas Kedokteran Universitas Malahayati angkatan 2018.

Metode: Penelitian ini bersifat survei analitik dengan pendekatan cross sectional dengan teknik pengambilan sampel jenis total sampling. Subjek dalam penelitian ini adalah seluruh mahasiswa Fakultas Kedokteran Universitas Malahayati Bandar Lampung Angkatan tahun 2018 sebanyak 119 responden. 
Pengambilan data dengan menggunakan kuesioner. Data yang diperoleh dianalisis secara statistik dengan uji chi-square.

Hasil: Sebagian besar subjek penelitian ini berjenis kelamin perempuan $73,9 \%$, berusia 20 tahun 35,\%, memiliki tingkat motivasi tinggi 45,4\%, tingkat stress sedang $45,5 \%$.

Kesimpulan: Terdapat hubungan yang signifikan antara hubungan stress dengan motivasi belajar

Kata Kunci : Stress, Motivasi Belajar

\section{PENDAHULUAN}

Kemajuan

era globalisasi

perkembangan

sekarang ini

diperlukan upaya yang signifikan khususnya bagi generasi penerus sebab akan membawa dampak kemajuan diberbagai bidang kehidupan tanpa terkecuali bidang kedokteran. Oleh karena itu untuk meningkatkan kualitas sumber daya manusia di bidang kedokteran institusi perlu meningkatkan kualitas mahasiswa kedokteran. Mahasiswa kedokteran dituntut untuk memiliki keterampilan, etika, moral, hukum, dan budaya yang senantiasa dipadukan dengan ilmu. Mahasiswa kedokteraen harus menjadi individu yang selalu belajar sepanjang hidupnya dan bisa fleksibel serta mampu mengumpulkan dan mengatur informasi dari berbagai sumber dan siap untuk menerapkan pengetahuan yang relevan untuk pemecahan masalah pasien dalam konteks kesehatan(Maulana, 2016). Sehingga dalam hal ini di perlukan motivasi belajar yang tinggi mahasiswa

$$
\text { Motivasi dalam belajar yang }
$$

tinggi memungkinkan akan memperoleh hasil belajar yang tinggi pula, artinya semakin tinggi motivasinya, semakin intensitas usaha dan upaya yang dilakukan, maka semakin tinggi hasil belajar yang diperolehnya. Mahasiswa melakukan berbagai upaya atau usaha untuk meningkatkan keberhasilan dalam belajar sehingga mencapai keberhasilan yang cukup memuaskan sebagaimana yang diharapkan. Di samping itu motivasi juga menopang upaya-upaya dan menjaga agar proses belajar mahasiswa tetap jalan. Hal ini menjadikan mahasiswa gigih dalam belajar (Cleopatra, 2016).

Mahasiswa adalah

sekelompok orang yang mudah mengalami stres. Stres pada mahasiswa dapat memberi berbagai dampak negatif baik dampak kognitif, dampak emosional maupun dampak fisiologis. Stres akan memunculkan dampak perilaku antara lain tidak semangat kuliah, malas mengerjakan tugas kuliah, menyalahgunakan obat terlarang maupun alkohol serta terlibat pada kesenangan yang berlebihan (Mahfar et al., 2007).

Berdasarkan penelitian

Riezky AK dan Sitompul AZ (2017) didapatkan hasil bahwa sebanyak 73 (55,3\%) mahasiswa fakultas kedokteran Universitas Abdulyatama yang memiliki motivasi belajar tinggi dan sebanyak 59 (44,7\%) yang memiliki motivasi belajar rendah. Sementara itu, Suciani dan Rozali (2014) mendapatkan sebanyak 45 $(34,6 \%)$ mahasiswa Universitas Esa Unggul dengan motivasi belajar rendah, kemudian sebanyak 47 $(36,2 \%)$ mahasiswa mempunyai motivasi belajar sedang, dan sebanyak 38 (29,2\%) mahasiswa 
memiliki motivasi belajar tinggi. Menurut hasil presurvai kepada 10 responden angkatan 2018 dengan menggunakan cara wawancara terdapat $80 \%$ memiliki motivasi belajar yang rendah hal ini di tujukan bahwa malasnya dalam belajar UTB dan UAB di karenakan stress, dan mengakibatkan mereka memiliki penuruanan motivasi belajarnya, sehingga ipknya menurun, dan banyaknya beban juga dapat mengakibatakn penurunan motivasi belajar

Salah satu faktor yang mempengaruhi motivasi belajar adalah stress (Rucker, 2012). Stres adalah suatu keadaan yang membebani atau membahayakan kesejahteraan penderita, yang dapat meliputi fisik, psikologis, sosial atau kombinasinya. Stress dapat menghasilkan berbagai respon, Berbagai peneliti telah membuktikan bahwa respon-respon tersebut dapat berguna sebagai indikator terjadinya stres pada individu, dan mengukur tingkat stres yang dialami individu (Purnama, 2017).

Seorang individu akan memiliki respon terhadap kejadian yang memicu adanya stres (stressor). Stres merupakan suatu keadaan yang tidak diinginkan seorang individu. Pada kondisi stres terjadi kesenjangan antara tuntutan lingkungan dengan kemampuan seorang individu untuk mengatasi stres (coping) (Santrock, 2007).

Menurut FernandezGonzalez (2015) stres juga dapat muncul karena tekanan untuk

\section{METODOLOGI PENELITIAN}

Penelitian ini bertujuan untuk mengetahui pengukuran variabel dan mencari hubungan antar variabel, dengan jenis penelitiannya menggunakan metode kuantitatif menunjukkan prestasi dan keunggulan akademik yang semakin meningkat. Hal tersebut dapat mengakibatkan mahasiswa akan merasa terbebani.Keadaan stress negatif pada seseorang akan mengakibatkan mahasiswa menjadi males dan tidak tertarik melakukan kegiatan. Salah satu bentuk stress negtif yaitu bentuk strss akademi dengan motivasi belajar (Mumpuni \& Wulandari, 2010). Akibatnya apabila seseorang mengalami stress akan menjadi penurunan minat belajar. Minat belajar adalah suatu ketertarikan seseorang terhadap belajar. Minat belajar merupakan alat yang mendorong seseorang bermotivasi dalam belajar (Djamarah, 2011). Menurut Sakamoto (2015) peningktan stress pada mahasiswa akan menurunkan tingkat motivasi seseorang.

Jika mahasiswa tidak memiliki kemampuan belajar, kondisinya tidak baik, kondisi lingkungan juga kurang kondusif serta upaya dosen dalam pembelajaran kurang, maka motivasi belajar menurun, sehingga dibutuhkan cara penanganan akan kondisi tersebut yang disebut stress. Dengan stress maka mahasiswa akan senantiasa mengoptimalkan motivasi belajarnya pada mata kuliah statistika, sesuai dengan pendapat Lazarus (dalam Prayascitta, 2010) Dari pemaparan di atas peneliti tertarik untuk meneliti hubungan antara stres terhadap motivasi belajar pada Mahasiswa Fakultas Kedokteran Universitas Malahayati angkatan tahun 2018.

dengan metode analitik. Dengan maksud apakah ada hubungan stres dengan motivasi belajar pada mahasiswa kedokteran Universitas Malahayati angkatan tahun 2018. Rencana penelitian ini menggunakan 
pendekatan cross sectional, pengumpulan datanya menggunakan kuisorner, yang di kumpul secara bersamaan dengan variabel dependen dan variabel independen. Lokasi penelitian ini di laksanakan di Kampus Universitas Malahayati.
Penelitian akan di lakukan bulan juni 2020 hingga selesai. Populasi penelitian ini adalah seluruh Mahasiswa Fakultas Kedokteran Universitas Malahayati angkatan tahun 2018 sejumlah 119 orang.

\section{HASIL PENELITIAN DAN PEMBAHASAN}

\section{Karakteristik Responden}

1. Jenis Kelamin Responden

Tabel Distribusi Frekuensi Jenis Kelamin Responden Mahasiswa Kedokteran Universitas Malahayati Angkatan Tahun 2018

\begin{tabular}{cccc}
\hline No. Jenis Kelamin & Jumlah & Presentase (\%) \\
\hline 1 & Perempuan & 88 & $73,9 \%$ \\
2 & Laki-laki & 31 & $26,1 \%$ \\
\hline & Jumlah & 119 & $100 \%$ \\
\hline
\end{tabular}

Berdasarkan tabel 1 di atas menunjukkan bahwa dari 119 responden, frekuensi paling banyak adalah jenis kelamin perempuan yaitu sebanyak 88 orang $(73,9 \%)$. Sedangkan responden yang berjenis kelamin laki-laki ada sebanyak 31 orang $(26,1 \%)$.

\section{Usia Responden}

Tabel Distribusi Frekuensi Usia Responden Mahasiswa Kedokteran Universitas Malahayati Angkatan Tahun 2018.

\begin{tabular}{llll}
\hline No. & Usia & Jumlah & $\begin{array}{l}\text { Presentase } \\
\text { (\%) }\end{array}$ \\
\hline 1 & 18 & 14 & $11,8 \%$ \\
2 & 19 & 36 & $30,3 \%$ \\
3 & 20 & 42 & $35,3 \%$ \\
4 & 21 & 15 & $12,6 \%$ \\
5 & 22 & 9 & $7,6 \%$ \\
6 & 23 & 3 & $2,5 \%$ \\
\hline & Jumlah & $\mathbf{1 1 9}$ & $\mathbf{1 0 0} \%$ \\
\hline
\end{tabular}

Berdasarkan tabel di atas menunjukkan bahwa frekuensi usia 18 tahun sebanyak 14 orang $(11,8 \%)$, usia 19 tahun sebanyak 36 orang $(30,3 \%)$, usia 20 tahun sebanyak 42 orang $(35,3 \%)$, usia 21 tahun sebanyak 15 orang $(12,6 \%)$, usia 22 tahun sebanyak 9 orang $(7,6 \%)$ dan usia 23 tahun sebanyak 3 orang $(2,5 \%)$. 
Analisa Univariat

\section{Tingkatan Stres Responden}

Distribusi Frekuensi Tingkatan Stres Responden pada Mahasiswa Kedokteran Universitas Malahayati Angkatan Tahun 2018

\begin{tabular}{cccc}
\hline No. & $\begin{array}{c}\text { Tingkatan } \\
\text { Stres }\end{array}$ & Jumlah & Presentase (\%) \\
\hline 1 & Ringan & 29 & $24,4 \%$ \\
2 & Sedang & 53 & $44,5 \%$ \\
3 & Berat & 30 & $25,2 \%$ \\
4 & Sangat Berat & 7 & $5,9 \%$ \\
\hline & Jumlah & $\mathbf{1 1 9}$ & $\mathbf{1 0 0 \%}$ \\
\hline
\end{tabular}

$\begin{array}{lllr}\text { Berdasarkan } & \text { tabel } & \text { di } & \text { atas } \\ \text { menunjukkan } & \text { bahwa } & \text { dari } & 119\end{array}$ responden didapatkan frekuensi terbanyak adalah tingkatan stress sedang yakni sebanyak 53 responden $(45,5 \%)$ dan frekuensi paling sedikit adalah tingkatan stress sangat berat yaitu sebanyak 7 responden $(5,3 \%)$, sedangkan stress ringan sebanyak 29 responden $(24,4 \%)$ dan stress berat sebanyak 30 responden $(25,2 \%)$.

\section{Tingkatan Motivasi Belajar}

Distribusi Frekuensi Motivasi Belajar Responden pada Mahasiswa Kedokteran Universitas Malahayati Angkatan Tahun 2018

\begin{tabular}{lrcl}
\hline $\begin{array}{l}\text { No. } \\
\text { Motivasi } \\
\text { Belajar }\end{array}$ & Jumlah & Presentase (\%) \\
\hline 1 & Tinggi & 54 & $45,4 \%$ \\
2 & Sedang & 35 & $29.4 \%$ \\
3 & Rendah & 30 & $25,2 \%$ \\
\hline \multicolumn{2}{l}{ Jumlah } & $\mathbf{1 1 9}$ & $\mathbf{1 0 0 \%}$ \\
\hline
\end{tabular}

Berdasarkan tabel di atas menunjukkan bahwa dari 119 responden didapati tingkatan motivasi belajar terbanyak adalah motivasi belajar tinggi yaitu sebanyak 54 orang $(45,4 \%)$ sdangkan frekuensi paling sedikit adalah motivasi belajar rendah yaitu sebanyak 30 orang $(25,2 \%)$. Sedangkan yang motivasi sedang ada sebanyak 35 orang $(29,4 \%)$. 


\section{Analisis Bivariat}

Tabel Hubungan Antara Stres Dengan Motivasi Belajar Pada Mahasiswa Kedokteran Universitas Malahayati Angkatan Tahun 2018

\begin{tabular}{|c|c|c|c|c|c|c|c|c|}
\hline \multirow{3}{*}{ Stres } & \multicolumn{6}{|c|}{ Motivasi Belajar } & \multirow{3}{*}{$\begin{array}{c}\text { OR } \\
\mathrm{Cl}(95 \%)\end{array}$} & \multirow{3}{*}{$\begin{array}{l}p- \\
\text { valu } \\
e\end{array}$} \\
\hline & \multicolumn{2}{|c|}{ Tinggi } & \multicolumn{2}{|c|}{ Sedang } & \multicolumn{2}{|c|}{ Rendah } & & \\
\hline & $\mathbf{N}$ & $\%$ & $\mathbf{N}$ & $\%$ & $\mathbf{N}$ & $\%$ & & \\
\hline Stres Ringan & 20 & $16,8 \%$ & 7 & $5,9 \%$ & 2 & $1,7 \%$ & & \\
\hline Stres Sedang & 22 & $18,5 \%$ & 17 & $14,3 \%$ & 14 & $11,8 \%$ & 5,86 & \\
\hline Stres Berat & 12 & $10,1 \%$ & 10 & $8,4 \%$ & 8 & $6,7 \%$ & $(4,65-$ & 01 \\
\hline $\begin{array}{c}\text { Stres Sangat } \\
\text { Berat }\end{array}$ & 0 & $0 \%$ & 1 & $0,8 \%$ & 6 & $5 \%$ & & \\
\hline
\end{tabular}

Berdasarkan tabel 4.5 diatas, dari 119 responden didapatkan hasil pada 29 responden dengan kategori stress ringan didapatkan sebanyak 20 $(16,8 \%)$ responden yang memiliki motivasi belajar yang tinggi, didapatkan sebanyak $7 \quad(5,9 \%)$ responden yang memiliki motivasi belajar yang sedang, didapatkan sebanyak $2(1,7 \%)$ responden yang memiliki motivasi belajar yang rendah.

Pada 53 responden dg kategori stress sedang didapatkan sebanyak $22(18,5 \%)$ responden yang memiliki motivasi belajar yang tinggi, didapatkan sebanyak 17 $(14,3 \%)$ responden yang memiliki motivasi belajar yang sedang, didapatkan sebanyak $14 \quad(11,8 \%)$ responden yang memiliki motivasi belajar yang rendah.

Pada 30 responden $\mathrm{dg}$ kategori stress berat didapatkan sebanyak $12(10,1 \%)$ responden yang

\section{PEMBAHASAN}

Belum banyak literatur yang membahas hubungan stres terhadap motivasi belajar, namun beberapa peneliti mengindikasikan bahwa stres dapat mempengaruhi motivasi. Penelitian yang dilakukan oleh Rucker, Park et al. dan Struthers didapatkan hasil yang sama bahwa terdapat hubungan yang signifikan memiliki motivasi belajar yang tinggi, didapatkan sebanyak 10 $(8,4 \%)$ responden yang memiliki motivasi belajar yang sedang, didapatkan sebanyak $8 \quad(6,7 \%)$ responden yang memiliki motivasi belajar yang rendah. Pada 7 responden dengan kategori stress berat di dapatkan sebanyak 0 responden yang memiliki motivasi belajar yang tinggi, didapatkan sebanyak $1(0,8 \%)$ responden yang memiliki motivasi belajar yang sedang, didapatkan sebanyak 6 (5\%) responden yang memiliki motivasi belajar yang rendah.

Berdasarkan uji statistik diperoleh nilai $p=0,001 \quad(p<0,05)$ maka dapat disimpulkan bahwa terdapat hubungan yang bermakna antara stres dengan motivasi belajar pada mahasiswa kedokteran Universitas Malahayati angkatan tahun 2018.

antara tingkat stress dengan motivasi belajar (Rucker,2012). Pada penelitian ini berdasarkan tabel 4.5 dilakukan analisa menggunakan uji chi-square didapatkan $p$-value 0,001 , dikarenakan nilai $p$-value 0,001 < 0,005 maka berdasarkan pengambilan keputusan dapat di 
simpulkan bahwa terdapat hubungan yang signifikan antara stress dengan motivasi belajar. Hubungan antara stres terhadap motivasi belajar yaitu semakin tinggi tingkat stress maka semakin menurunkan minat belajar mahasiswa sebaliknya semakin rendah tingkat stress semakin tinggi motivasi belajar.

Hasil penelitian ini sejalan dengan penelitian yang dilakukan oleh Sakamoto 2015 bahwa semakin tinggi tingkat stress seorang mahasiswa maka dapat diprediksikan semakin rendah tingkat motivasinya (Sakamoto,2015). Penelitian yang dilakukan Park 2012 juga memperlihatkan makin tinggi tingkat stres mahasiswa maka akan menyebabkan menurunnya dorongan mahasiswa untuk lebih termotivasi. Selain itu hal lain yang dapat mempengaruhi hubungan antara stres terhadap motivasi belajar dapat dilihat dengan adanya strategi manajemen stres yang baik. Mahasiswa yang memiliki strategi manajemen stres yang baik dapat meningkatkan motivasi belajar mahasiswa tersebut, dengan adanya motivasi belajar yang tinggi maka prestasi akademik mahasiswa pun akan meningkat (Park, 2012).

Penelitian yang dilakukan Struthers 2000 menunjukkan apabila terdapat mahasiswa yang memiliki tingkat stress yang berat dan mampu memanajemen stresnya dengan sangat baik, maka akan meningkatkan motivasi yang telah dimilikinya. Sehingga dapat disimpulkan salah satu faktor yang ikut mempengaruhi hubungan antara stres dan motivasi belajar yaitu adanya manajemen stres yang baik (Struthers, 2000). Pada penelitian yang dilakukan oleh Faras 2018 terhadap mahasiswa tingkat pertama fakultas kedokteran universitas lampung tahun 2018 didapatkan hasil analisa menggunakan uji chi- square yaitu $p$ - value $0,019<0,05$ sehingga terdapat hubungan yang signifikan antara stress dan motivasi belajar (Faras 2018).

Hasil penelitian Fadillah (2013) menyebutkan bahwa ada beberapa masalah yang muncul dan menghambat penyelesaian tugas akhir salah satunya adalah stres. Jatuhnya mental dan turunnya optimisme di tengah pengerjaan tugas akhir disebabkan karena hambatan yang ditemui dan tidak adanya keinginan untuk berusaha (Fadillah, 2013).

Penelitian yang dilakukan Taufik (2019) didapatkan hubungan yang signifikan antara stres dengan motivasi belajar, dengan nilai sig. 0.000. Hal ini membuktikan bahwa stres memiliki hubungan yang kuat terhadap motivasi belajar mahasiswa. Menurut Taufik (2019) bahwa dengan adanya stres akan memicu terjadinya penurunan motivasi belajar pada mahasiswa dan pada akhirnya akan mempengaruhi prestasi akademik mahasiswa. Stres belajar merupakan keadaan individu yang mengalami tekanan hasil persepsi dan penilaian tentang stressor akademiknya, yang dapat diartikan sebagai bentuk dari kejenuhan terhadap rutinitas dari kegiatan belajar yang dilakukan mahasiswa secara terus menerus. Sedangkan motivasi belajar adalah dorongan internal dan eksternal pada siswa yang sedang belajar, dimana bertujuan untuk melakukan perubahan yang lebih baik (Uno, 2011)

Selain itu tingkat stres yang tidak berpengaruh terhadap motivasi belajar pada subjek dapat pula disebabkan oleh pengelolaan stres yang baik. Menurut Rickard (2000) sebenarnya stres dapat merupakan motivasi yang dibutuhkan oleh individu untuk bergerak dan merupakan suatu energi yang dapat digunakan secara efektif 
(Rickard,2000) Hal itu sejalan dengan pendapat Prawitasari (1988) bahwa stres dapat merupakan tantangan dan motivasi seseorang untuk bergerak ke arah yang lebih baik, tetapi stress yang terlalu berat

\section{KESIMPULAN}

Berdasarkan hasil penelitian tentang hubungan antara stres terhadap motivasi belajar pada Mahasiswa Fakultas Kedokteran Universitas Malahayati angkatan tahun 2018 dapat disimpulkan:

1. Diketahui distribusi frekuensi stres pada Mahasiswa Fakultas Kedokteran Universitas Malahayati angkatan tahun 2018 diperoleh sebagian besar pada kelompok tingkatan stres sedang sebanyak $44,5 \%$.

2. Diketahui distribusi frekuensi motivasi belajar pada

\section{DAFTAR PUSTAKA}

Agata, A. K., \& Warsito, B. E. (2016). Gambaran faktor-faktor yang mempengaruhi motivasi belajar mahasiswa program studi ilmu keperawatan universitas diponegoro semarang (Doctoral dissertation, Faculty of Medicine).

Amirudin I, (2019). Stress Dan Motivasi Belajar Mahasiswa Profesi Keperawatan The Stress Levels And Learn Motivation In Nursing Program. Lampung. Wacana Kesehatan.

Calaguas, G. M. (2011). College academic stress: Differences along gender lines. Journal of Social and Development sciences, 1(5), akan menjadi sesuatu yang mengganggu kestabilan diri seseorang dan akan membawa penderitaan bagi yang mengalaminya (Prawitasari,1988).
Mahasiswa
Fakultas
Kedokteran Universitas
Malahayati angkatan tahun 2018 diperoleh sebagian besar pada kelompok motivasi belajar sebanyak $45,4 \%$.

3. Terdapat hubungan yang singnifikan antara stres dengan motivasi belajar pada Mahasiswa Fakultas Kedokteran Universitas Malahayati angkatan tahun 2018, dibuktikan dengan nilai $\mathrm{p}(0,001<0,05)$ dengan $\mathrm{OR}$ 5,86 .
194-201.

Demolingo, D. P. A., Kalalo, F., \& Katuuk, M. E. (2018). Hubungan Stres Dengan Motivasi Belajar Pada Mahasiswa Semester $V$ Program Studi IImu Keperawatan Fakultas Kedokteran Universitas Sam Ratulangi Manado. Jurnal Keperawatan, 6(1).

Deyisi Pratiwi. A. Demolingo Flora.k. Mario Katu. (2018)., Hubungan stress dengan motivasi belajar pada mahasiswa semester $V$ program studi ilmu keperawatan fakultas kedokteran universitas SAM Ratulangi manado.

Djamarah, S. B. (2011). Psikologi 
Belajar. Jakarta: Rineka Cipta.

Fadillah AER. (2013). Stres dan motivasi belajar pada mahasiswa psikologi universitas mulawarman yang sedang menyusun skripsi. Ejournal Psikologi; 1 (3): 254267.

Fernández-González, L., GonzálezHernández, A. \& TrianesTorres, M.V. (2015). Relationships Between Academic Stress, Social Support, OptimismPessimism And Self-Esteem In College Students. Electronic Journal of Research in Educational Psychology. 13(1):111-30.

Halan, Y.C., 2005. Managing Stress. Berkshire: New Dawn Press.

Mahfar, M., Zaini, F. \& Nordin, N.A. (2007). Analisis Faktor Penyebab Stres Di Kalangan Pelajar. Jurnal Kemanusiaan. 9:63-71.

Mulyaningsih, I. E. (2014). Pengaruh Interaksi Sosial Keluarga, Motivasi Belajar, Dan Kemandirian Belajar Terhadap Prestasi Belajar. Jurnal Pendidikan dan Kebudayaan, 20(4), 441-451.

Park J, Chung S, An H, Park S, Lee C, Kim SY,et al. (2012). A structural model of stress motivation, and academic performance in medical students. J Psychiatry Investig.;9(1):143-9.

Pratama \& Rusmawati. (2017). Hubungan Dukungan Sosial
Teman Sebaya Dengan

Motivasi Belajar Dalam

Program Sekolah Lima Hari Di

SMAN 5 Semarang. Skripsi.

Universitas Diponegoro,

Semarang.

Rucker J. (2012). The relationship betweenmotivation

perceived stress and academic achievement in students. Twente: University of Twente;

Sakamoto, R. (2015). The relationship between motivation, second language learning, and stress

Sakamoto R. (2015). The relationship between motivation, second language learning, and stress in international students. Missouri: University of Central Missouri;

Ulya, I. F., Irawati, R., \& Maulana, M. (2016). Peningkatan Kemampuan Koneksi Matematis Dan Motivasi Belajar Siswa Menggunakan Pendekatan Kontekstual. Jurnal Pena Ilmiah, 1(1), 121130.

Yusoff, M.S.B. \& Rahim, A.F.A. (2010). The Medical Student Stressor Questionnaire (MSSQ) Manual. Kota Bharu: KKMED Publication.

Zainaro, M. A. (2021). The Leadership and Motivation on Inpatient Compliance in Preventing the Risk of Patients Falling. Psychology and Education Journal, 58(2), 241-253. 